\title{
The relationship between Hypertension and weight status in Iraqi population
}

\author{
Issa M. Kadhim * \\ Received 31, May, 2010 \\ Accepted 16, September, 2010
}

\begin{abstract}
:
Most medical books and researches documented that increased body weight is a predisposing factor to hypertension, and there is recent work in this field as well.

In this research, the relationships between hypertension and body weight with age were studied in Iraqi population .

It is concluded that diastolic hypertension is separated from systolic and combined hypertension and increased body weight has little effect on increased blood pressure.
\end{abstract}

Key words: Medical physics, Hypertension, Body weight, BMI, diastolic hypertension

\section{Introduction:}

Persistent hypertension is one of the risk factors for strokes, heart attacks, heart failure and arterial aneurysm and is a leading cause of chronic renal failure. At severely high pressures, a person can expect to live no more than few years unless appropriately treated [1].

Over time, the number of collagen fibers in artery and arteriole walls increases making blood vessels stiffer, with reduced elasticity comes a smaller cross-sectional area in systole, and so a raised mean arterial blood pressure [1]. Over $91 \%$ of adult hypertension has no clear cause and is therefore called essential or primary hypertension. often it is part of the metabolic syndrome in patients with insulin resistance. It occurs in combination with diabetes mellitus (type 2), combined hyperlipidemia and central obesity [2].

There are so many series of studies on hypertension, the most widely quoted is Framingham heart study carried out in an American town :Framingham, Massachusetts and the other in Busselton, Western Australia .
In this paper, the relationships between hypertension and body weight represented by the body mass index were studied as a preliminary study to be extended in the next work according to the results.

\section{Materials and Method:}

Males and females were grouped into Five age groups according to their ages . Group 1 between(16-20) years, group 2 between (21-25) years, group 3 between (26-30) years, group 4 between (31-35)years and the last group which is group 5 between (3640) years.

15 males and 15 females were taken in each age group and their height and weight were measured and the body mass index of every subject was calculated according to the well-known formula $\mathrm{BMI}=$ Body weight $(\mathrm{Kg}$ $/[\text { height }(\mathrm{m})]^{2}$. where $\mathrm{Kg}$ is the subject weight in Kilograms and $\mathrm{m}$ is the height in meters which is simple and widely used method for estimating body fat .

*University of Baghdad- College of Science for women - physics Department 
The definition of weight status were according to that published in 2000 by WHO and provided the following values[3] .

A BMI less than 18.5 is under weight

A BMI of 18.5-24.9 is normal weight

A BMI of 25.0-29.9 is over weight

A BMI of 30.0-39.9 is obese

A BMI of 40.0- or higher is severely obese.

Their blood pressure were measured several times and mean was calculated then categorized as hypertensive according to those definitions by Chobanian (2003) that hypertension is considered to be present when a person's systolic blood pressure is consistently $140 \mathrm{mmHg}$ or greater , and/or their diastolic blood pressure is consistently $90 \mathrm{mmHg}$ or greater[4].

\section{Results and Discussion:}

As seen in table1 and figure $1,5.33 \%$ of males and $8 \%$ of females are under weight ,38.67\% of males and 52\% of females are normal weight , $37.33 \%$ of males and $33.3 \%$ of females were overweight and $18.67 \%$ of males and $6.67 \%$ of females were obese.

Table 1 :The weight Status of males and females

\begin{tabular}{|c|c|c|c|c|}
\hline \multirow{2}{*}{$\begin{array}{l}\text { Weight } \\
\text { Status }\end{array}$} & \multicolumn{2}{|c|}{ Males } & \multicolumn{2}{c|}{ Females } \\
\cline { 2 - 5 } & Number & Percentage & Number & Percentage \\
\hline $\begin{array}{c}\text { Under } \\
\text { weight }\end{array}$ & 4 & 5.33 & 6 & 8 \\
\hline $\begin{array}{c}\text { Normal } \\
\text { weight }\end{array}$ & 29 & 38.67 & 39 & 52 \\
\hline overweight & 28 & 37.33 & 25 & 33.33 \\
\hline Obese & 14 & 18.67 & 5 & 6.67 \\
\hline Total & 75 & 100 & 75 & 100 \\
\hline
\end{tabular}

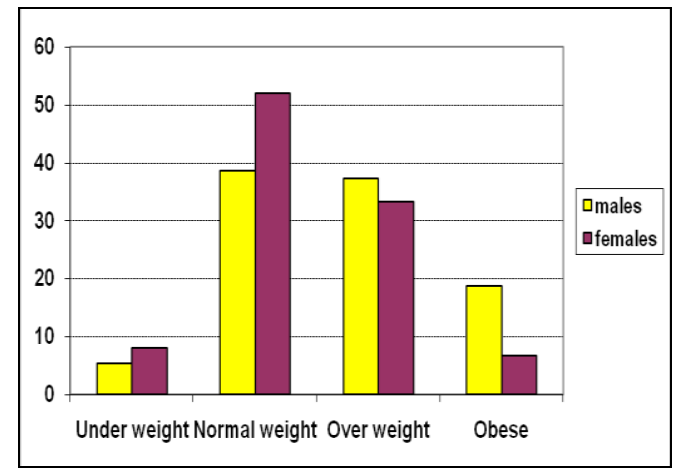

Fig. 1: Percentage of males and females according to their weight
It can be seen in table 2 and figure2, that $66.67 \%$ of males and $76 \%$ of females were normotensive and $12 \%$ of males and $10.67 \%$ of females suffered from systolic hypertension, and $6.67 \%$ of both males and females had Diastolic hypertension and $14.67 \%$ of males and $6.67 \%$ of females had both systolic and diastolic hypertension .

Table 2: Blood Pressure of males and females

\begin{tabular}{|c|c|c|c|c|}
\hline Blood & \multicolumn{2}{|c|}{ males } & \multicolumn{2}{|c|}{ females } \\
\cline { 2 - 5 } Pressure & no. & percentage & no. & percentage \\
\hline $\begin{array}{c}\text { Normal Blood } \\
\text { Pressure }\end{array}$ & 50 & 66.67 & 57 & 76.00 \\
\hline $\begin{array}{c}\text { Systolic } \\
\text { Hypertension }\end{array}$ & 9 & 12.00 & 8 & 10.67 \\
\hline $\begin{array}{c}\text { diastolic } \\
\text { Hypertension }\end{array}$ & 5 & 6.67 & 5 & 6.67 \\
\hline $\begin{array}{c}\text { Systolic and } \\
\text { Diastolic } \\
\text { Hypertension }\end{array}$ & 11 & 14.67 & 5 & 6.67 \\
\hline
\end{tabular}

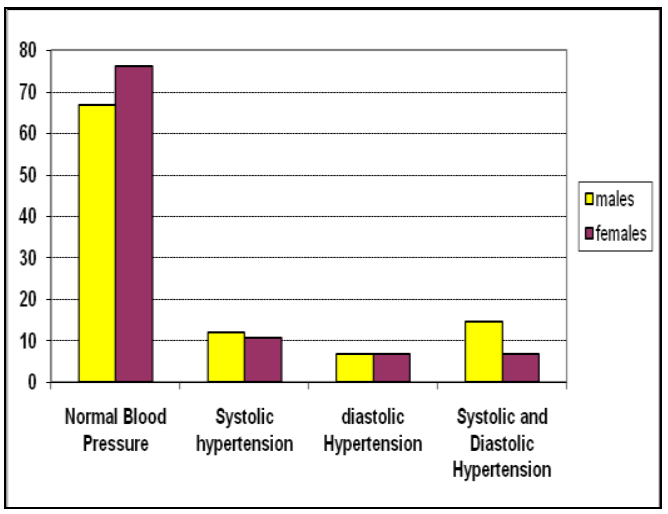

Fig. 2: Blood Pressure of males and females (percentage)

Table and fig. 3 show that $25 \%$ of underweight males and $16 \%$ of underweight females are hypertension . About $33 \%$ of males and $47 \%$ of females are normotensives with normal weight subjects in both genders . $2.7 \%$ of males and $1.3 \%$ of females are normally weighted at sustained systolic and diastolic hypertension . All subjects with body weight above normal in both genders are seen in table 3 presented together in fig. 3 . 
Table 3: relation between Blood pressure and weight

\begin{tabular}{|c|c|c|c|c|}
\hline \multirow{2}{*}{ condition } & \multicolumn{2}{|r|}{ males } & \multicolumn{2}{|c|}{ femlaes } \\
\hline & no. & percentage & no. & percentage \\
\hline $\begin{array}{c}\text { under weight } \\
\& \\
\text { normotensive }\end{array}$ & 3 & 4.00 & 5 & 6.67 \\
\hline $\begin{array}{c}\text { under weight } \\
\text { \& systolic } \\
\text { hypertension }\end{array}$ & 1 & 1.33 & 1 & 1.33 \\
\hline $\begin{array}{c}\text { normal weight } \\
\& \\
\text { normotensive }\end{array}$ & 25 & 33.33 & 35 & 46.67 \\
\hline $\begin{array}{c}\text { normal weight } \\
\text { \& systolic } \\
\text { hypertension }\end{array}$ & 2 & 2.67 & 3 & 4.00 \\
\hline $\begin{array}{c}\text { normal weight } \\
\text { \& diastolic } \\
\text { hypertension }\end{array}$ & $\mathbf{0}$ & 0.00 & $\mathbf{0}$ & 0.00 \\
\hline $\begin{array}{l}\text { normal weight } \\
\text { with systolic } \\
\text { and diastolic } \\
\text { hypertension }\end{array}$ & 2 & 2.67 & 1 & 1.33 \\
\hline $\begin{array}{l}\text { over weight \& } \\
\text { normotensive }\end{array}$ & 18 & 24.00 & 14 & 18.67 \\
\hline $\begin{array}{c}\text { over weight \& } \\
\text { systolic } \\
\text { hypertension }\end{array}$ & 5 & 6.67 & 3 & 4.00 \\
\hline $\begin{array}{c}\text { over weight \& } \\
\text { diastolic } \\
\text { hypertension }\end{array}$ & 3 & 4.00 & 5 & 6.67 \\
\hline $\begin{array}{c}\text { overweight } \\
\text { with systolic } \\
\text { and diastolic } \\
\text { hypertension }\end{array}$ & 2 & 2.67 & 3 & 4.00 \\
\hline $\begin{array}{c}\text { obese } \& \\
\text { normotensive }\end{array}$ & 5 & 6.67 & 3 & 4.00 \\
\hline $\begin{array}{c}\text { obese \& } \\
\text { systolic } \\
\text { hypertension } \\
\end{array}$ & 1 & 1.33 & 1 & 1.33 \\
\hline $\begin{array}{c}\text { obese } \& \\
\text { diastolic } \\
\text { hypertension }\end{array}$ & 2 & 2.67 & $\mathbf{0}$ & 0.00 \\
\hline $\begin{array}{c}\text { obese with } \\
\text { systolic and } \\
\text { diastolic } \\
\text { hypertension }\end{array}$ & 6 & 8.00 & 1 & 1.33 \\
\hline
\end{tabular}

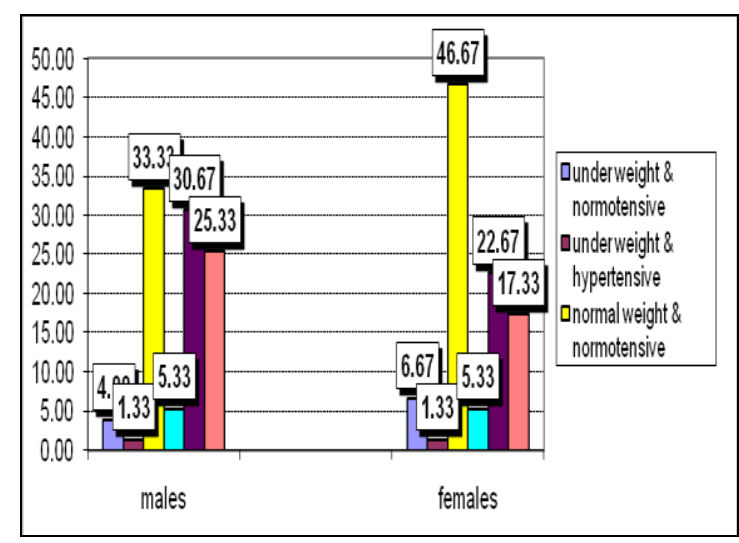

Fig. 3: The relationship between weight status and blood pressure condition as a percentage in males and females
Obesity is zero\% in female of age group5 .

Obesity is zero \% in males and females of age group2. From our previous study[5] in most of age groups and in both Genders, there is a prevalence of hypertension between $(20-30 \%)$ as it can be seen in table and Figure 4 .

Table4: The relationship between Hypertension and age

\begin{tabular}{|l|l|l|}
\hline $\begin{array}{l}\text { Age group in } \\
\text { years }\end{array}$ & $\begin{array}{l}\text { Hypertensive } \\
\text { males(\%) }\end{array}$ & $\begin{array}{l}\text { Hypertensive } \\
\text { females(\%) }\end{array}$ \\
\hline $16-20$ & 26.67 & 26.67 \\
\hline $21-25$ & 20.00 & 26.67 \\
\hline $26-30$ & 60.00 & 33.33 \\
\hline $31-35$ & 33.33 & 0.00 \\
\hline $36-40$ & 26.67 & 33.33 \\
\hline
\end{tabular}

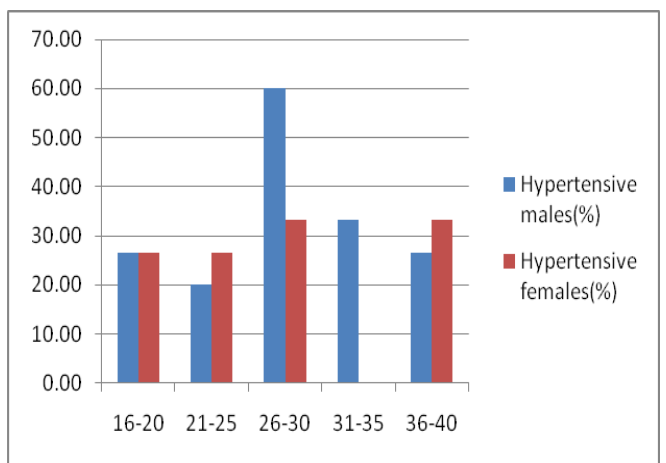

Fig. 4: The relationship between Hypertension and age

The exceptions are males of age group (26-30) and females of age group (31-35) where $60 \%$ of males at age 26-30 suffer from uncontrolled hypertension and on the contrary (zero\%) of females at age (31-35) has sustained uncontrolled hypertension . This actually needs very detailed and expanded further study. Especially if our previous published study[5] on obesity is correlated with this one, and it can be noticed that female age group (31-35) has zero\% obesity as well.

Where as ,males age group (26-30) has the maximum hypertension prevalence which is $60 \%$ but has obesity of less than $35 \%$ and the maximum prevalence of overweight up to the age of 40 years so still it can be coincided 
that Body weight above normal BMI has strong relation with uncontrolled hypertension in both genders .

It can be said that females look after their general health particularly blood pressure control more than males and this is obvious in age groups (26-30) and (31-35) year old subjects .

If the exceptions are excluded from the analysis, it can be analyzed that uncontrolled hypertension has no any correlation with age . But strong relation is noticed between uncontrolled hypertension with overweight and obesity .

So uncontrolled hypertension in males is more serious and has to be fully investigated particularly in the male young age groups . All over weight and obese subjects should be advised to be carefully examined and investigated to exclude any other pathology that can cause hypertension besides the increased weight status.

Table and fig. 3 show that $25 \%$ of underweight males and 16\% of underweight females are hypertension .

About $33 \%$ of males and $47 \%$ of females are normotensives with Normal with Normal weight subjects in both genders . $2.7 \%$ of males and $1.3 \%$ of females are normally weighted at sustained systolic and diastolic hypertension . All subjects with body weight above normal in both genders are seen in table 3 presented together in fig. 3 .Table and fig. 4 presented the relationship between hypertension and age . It is clear that above (20-30) \% of both genders have hypertension in all studied age groups except males of age groups (26-30) who has $60 \%$ and $0 \%$ of females at age group (31-35).

It is interesting to find that normal weight subjects do not suffer from pure diastolic hypertension as seen in table and figure 3 while there is significant number of subjects who have systolic or combined systolic and diastolic hypertension with abnormal body weight. From this it can be concluded that diastolic hypertension has different pathological process that is not related to age as well as body weight and should be categorized as a separate disease . Although many said that there is relation between age and hypertension this study showed that this disease occur in all age groups in the same prevalence . this counteracts with the theory of a atherosclerosis due to aging process as a strong predisposing factor to hypertension and there should be a pathological process behind not related to age .

It can be concluded that diastolic hypertension is a different disease from systolic and combined hypertension .

And that there is a pathological process behind hypertension and above weight status as a cause of both conditions if presented together and above weight status preferably is not regarded as a predisposing factor.

\section{References:}

1.Guyton and Hall. 2007, Textbook of Medical physiology. 7 th Ed., Elsevier- Saunders ,London, p220 .ISBNO-7216-0240-1.

2.Luma GB, Spiotta RT 2006. "Hypertension in children and adolescents." Am Fam physician 73(9):1558-68

3.World Health Organization technical report series 894.2000. "Obesity : Preventing and managing the global epidemic "Genera:world Health Organization.

4.Chobanian AV 2003. "The seventh Report of the joint National committee on Prevention ,Detection ,Evaluation and treatment of High blood pressure."JAMA 289:2560-72.

5.Kadhim, Issa Mohammad, Raja Nader, Nisreen Khalel 2010, “ Age related obesity and underweight in Iraqi population.”, The seventeenth scientific conference of Mustansirya College of education" 
العلاقة بين ارتفاع ضغط الدم وبين وزن الجسم في المجتمع العراقي

عيسى محهـ كاظمر

*جامعة بغاد - كلية العلوم للبنات - قسم الفيزياء .

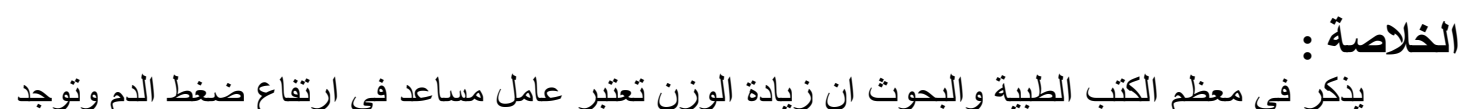

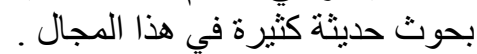
اجري هذا البحث في المجتمع العر اقي واخذ بنظر الاعتبار عامل العمر لكونه له علاقاقة بالوزن وزيادنه.

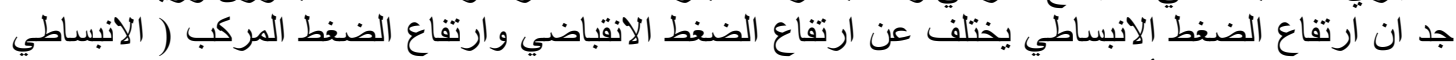
و الانقباضي معا) وان تأثير زيادة وزن الجسم قليل جدا. 